\title{
Best of Luck: The Education of Norman Felton
}

\author{
NOR M A N F L TON
}

Editor's Note: Norman Felton was born in London on April 29, 1913, the son of John Felton, a lithographer, and Gertrude Anne Felton, a cleaning woman. When Norman was 13 he left school to go to work and in 1929 the family emigrated to the United States. They settled in Cleveland, Ohio, where Norman worked at a variety of jobs. Later he and three friends traveled across the country, eventually spending some time in Seattle. Returning to Ohio in 1935, he became a truck driver, but left to attend The University of lowa where he received a bachelor's degree in 1940 and a master's in 1941. In 1940 he married Aline Stotts. His career began when he directed community theaters in St. Paul and Saginaw and later became a producer-director for NBC in Chicago doing dramatic radio programs. By 1950 he was in New York directing live television shows. (In 1952 he won an Emmy award for Robert Montgomery Presents.) During the 1960s he was involved in a number of classic television series including "The Man from U.N.C.L.E." and “Dr. Kildare.” In 1975 he produced the made-for-television film Babe and in 1979 And Your Name Is Jonah. The following essay is adapted, with the author's permission, from a long unpublished autobiographical work.

January 1936 was a cold month in Cleveland, Ohio. I'd been driving a moving van one wet, miserable day, and the gears of the Divco truck were unfamiliar to me. Carrying furniture out of one house, with ice underfoot, and then across town to unload it in another wasn't my idea of fun. By early evening I found myself dead tired.

Yes, a miserable day, yet in another sense I felt satisfaction in holding a card in the Teamsters' local. Work was hard to come by in 1936, and truck driving was a much-sought-after job. l'd never expected to have it so good, at least until I met Clancy.

Nearing East 105th Street and Euclid Avenue, I turned into an old building and climbed a couple of stairs to a cozy place where I knew it would be warm and I could get a drink. I noticed there was a new bartender as I asked for Seagrams Five Crown. At least, I'm quite sure that's what I asked for. The man slid the drink along and I downed it, pushing forward some coins as I did so. The bartender yelled, "a dime 
short, kid." "What? for Five Crown?"' I asked.

"You asked for Seven Crown and that's what you got," he snorted. "What's going on here?" I asked, looking around for a witness. It was dark, and I edged myself off the stool, fumbling in my pocket. It was then that I met Clancy.

Clancy Cooper was about six feet tall and looked lean and tough. He came up beside me and tossed a dime on the bar.

"Thanks," I said and started out. "Wait for me," he replied. I did, and he bought himself a drink, laughing as he did. Then, with his arm around me, we left the place.

Clancy walked alongside me as I headed for a trolley stop. He turned out to be the director of a group of amateur players in a community theater in Cleveland Heights. What he was doing down at Euclid and 105th Street I do not know. Years later, when I was in Hollywood, where he had been working as an actor for many years, we had lunch together. When I asked him how he happened to come forward as he did, he replied, "I caught a touch of cockney in your speech and you sounded funny, and I was also interested in the row of Teamster Union buttons on your cap."

Clancy had graduated from the drama school at Carnegie Tech in 1935, having drifted there from his home in Montana, stopping over on the way for a couple of years at The University of Iowa.

That night I did not go home on the trolley. The exhilaration of listening to my new-found friend dispelled any tired feeling. Around the corner was parked a car Clancy had borrowed, and he took me up to Cleveland Heights where his theater group was headquartered in an empty store. It was there that members met to read and rehearse plays, presenting them in any auditorium or theater available.

From that night forward almost every evening, as well as days off, found me helping to construct scenery, working backstage, and listening to play readings. One evening I tuned in to a serious discussion between Clancy and a committee concerning a play which they wanted to produce but which had too high a "royalty." "What is a royalty?" I asked as the meeting broke up. A woman, Dr. Dina Rees Evans, explained that it was a sum of money to be paid to the publisher and playwright. That answer was to turn my life around. "Why don't you write your own plays," I naively asked. "If you wrote them, you wouldn't have a problem." Those listening laughed and one of them said, "Why don't you try it, Norman?"

And why not? I had read playscripts while working backstage. I knew that a writer puts the name of a character in the middle of the page and what he is to say directly underneath. And I'd had a chance to read radio scripts. So I started to write, and the product, helped by Dr. Dina Rees 
Evans and Clancy Cooper, eventually brought me to the attention of the drama department of The University of Iowa, where I enrolled and where I met Aline Stotts, who was to be my wife. After leaving the University I was to make my living by directing community theaters in the Midwest, and then, in Chicago and New York, by producing and directing in radio and television. The lure of working with motion picture films brought us finally to California.

While struggling with pencil and paper, I happened to meet Mrs. Carlson, whom I knew because she had lived in the same apartment building occupied by my family when we first came to Cleveland. When she found out I was trying to write a play, she took me to her apartment and handed me an old portable Corona typewriter. On this gift I taught myself to type with two fingers, the same two digits I use to this day. As I hammered at the keys of that old typewriter I knew I was "in luck." From that time forward I never turned back from a course which would lead me into many areas of the theater and allied arts. It was luck and acknowledging "the moment."

As a boy I had been taken by my mother to see a pantomime and was enthralled; as a teenager I had stood in line for a sixpenny seat in the top balcony to see a performance of The Tempest; in America I had performed in a radio play and acted at the Seattle Repertory Theatre. But never once did I consider a career in the theater. The theater? How absurd!

Since that magic moment when someone said, "Why don't you write a play, Norman?" I was to devote myself to the theater. I remember thinking that I must, somehow, find a way to work in the theater all of my days. An unexpected surprise popped up when two traveling theater companies, Otis Skinner and Maude Adams in The Merchant of Venice and George M. Cohan in Pigeons and People came to Cleveland, and I received "extra" work at $\$ 1$ a performance. In other words, I had become "stage struck!"

I actually had the effrontery to ask Clancy to let me act! And he did! I played in The Weavers, a naturalistic social drama by Gerhart Hauptmann, in the part of a cruel foreman (I knew how to play that kind of man); then the group produced a play by Lynn Riggs called Cherokee Night, concerning social problems in the lives of Indians. I played a cowboy (about which I had nothing to draw on) and I have a photo sent to me recently by an old friend, to prove I did play the part. Then Clancy cast me in a lead, if you can imagine it, in a play by George S. Kaufman 
entitled The Butter and Egg Man. It was a comedy, and I played the title role of a young man from Ohio who comes to New York and gets involved in some schemes set by "city fellas." I still had a bit of a cockney, or, excuse me, "Brixton" accent. Clancy was a better actor than a director. I was frightened by having to memorize so many lines in the play, and wished I hadn't said I'd do it. But I did. After all, I had played Oberon, "King of the Fairies," in Seattle, and I hadn't anything to draw on for that.

It was, I believe, late in 1936 that Clancy and Dina Rees Evans encouraged me to try to find a way to go to The University of Iowa to work with the head of the Department of Drama, who they said was the best teacher of playwriting in the country. Clancy also said that I could probably (almost certainly, he said) obtain a Rockefeller Fellowship in Playwriting, which he had heard was available. I do not believe Dina Rees Evans went that far, for she knew better. I'm sure that she did not contradict Clancy, who spoke out of enthusiasm, because it might have confused me and interfered with my lively interest. The idea that I might not only write under the instruction of one they considered a terrific teacher of playwriting, but also obtain a college education while being paid, sounded marvelous.

Acting on their suggestions, I wrote a letter to Professor E. C. Mabie, chairman of the Department of Speech and Drama at The University of Iowa telling of my background, desire to study playwriting with him, and eagerness to obtain financial help (perhaps one of those Rockefeller Playwriting Fellowships?) I also sent samples of my writing of scenes for the stage. I hesitated to call them plays.

A few weeks later I received a short note from Professor Mabie, saying that I would no doubt benefit by attending the University. I was ecstatic. I sold my car for $\$ 75$ and began preparations to travel to lowa City. A brochure which accompanied his letter announced the opening of the second semester in February, and this was now mid-January. My old friends of the 105th Street gang gave me a farewell party, and members of the theater group also.

Packing my belongings in two old bags, I took a bus to Iowa City, arriving on a Saturday, prior to registration. I had $\$ 93$.

\section{III}

Earlier the previous year I had met a man named Marcus Bach. He was a minister of a small church in the Cleveland suburbs, serving while the regular pastor was on sabbatical leave. Marcus enlisted three other members of the theater group and myself to put on some short plays he 
had written, at various churches in the Cleveland area on Sunday evenings. He, too, was interested in playwriting, was on the staff of the Department of Religion at The University of Iowa, and knew Dina Rees Evans. As he had returned to the University, I had written to him and received a reply to the effect that I should contact him and his wife when I arrived and they would help me.

Arriving in lowa City, then, I made my way to the address he had given me. On the door of the apartment was tacked a message to me. It said that they were going out of town, but that I should go to see the Reverend Worthley, pastor of the Unitarian Church.

Carrying my bags I walked to the home of Reverend Worthley. His wife came to the door and I announced my arrival. She smiled and invited me in. Her husband soon appeared, and when I told them of the note Marcus Bach had left they just nodded and asked me if I would like to have some coffee and a sandwich. It wasn't until a few years later I discovered that Bach had evidently forgotten to tell them about my coming. It did not matter to them. They were wonderful. Not only did they show me to a bedroom where I could stay until I was registered at school and had a room, but they called two girls who lived nearby and were students, to come over and perhaps be of help in answering questions about registration and the like. They were lovely girls, and at the end of the afternoon suggested that if I wished, I could come to their house for dinner, which their mother was preparing. I went with them to dinner. The evening was delightful. The sisters lived with their mother, who had a Ph.D. in history. All three were anxious to answer my questions and ply me with information, though their efforts were often confusing, as all three answered my questions at the same time, and usually quite differently, whereupon they would argue among themselves and I never knew who was right. Nevertheless, I enjoyed their companyenormously. I returned to the home of Reverend Worthley quite late, but the door was not locked, and I crept quietly up to my room.

The next morning the young ladies came to escort me to church. The afternoon I spent poring over University literature and catalogs. When evening came I was invited by Reverend Worthley to attend a Sunday night meeting at the church hall where two former Rhodes scholars were to talk on the difference between university education in England and in the United States.

One of them was Paul Engle, who later headed the Writers' Workshop in the Iowa English department. Both men spoke glowingly about the system in British schools and the freedom to study without the "credit" system. It was truly, I felt, a "put down" of the American way. Of course, I really knew nothing about the running of universities in either country, 
but when the question period came, my hand shot up. I pointed out that while much of what they said might be true, it was extremely difficult, almost impossible in fact, for the lower classes in England to obtain university educations. For some reason my statement caused quite a stir, though it really wasn't to the point. I was pleased, however, to observe Worthley smiling.

Monday morning I went to see Professor Mabie. After a long wait in his office, I was admitted and introduced myself. It soon became apparent that Rockefeller Fellowships, when available, were for graduate students, which left me out. He told me that I should stay, register, and plan to take a degree. It would be a four-year course. At that point I was ready to get up and leave, not knowing what else to do, having only $\$ 93$.

Mr. Mabie insisted, however, that all was not lost. I could register as an out-of-state student for eight hours of credits that semester for about $\$ 60$. Then, he said, I could get work through the proper student help department to pay for rent and food. The idea of a commitment for a four-year program seemed out of all reason, to me, but he was insistent and would not take "no" for an answer. He led me to the door and wished me luck. Go over to the registrar's office, he said, closing his door.

At the registrar's office they asked about my high school credits. Of course, I didn't have any. They suggested that I write to my school in England; meanwhile they could register me as a "special" student. I filled out papers, paid the fee for eight credits, which they said would amount to about half the usual amount per semester. They added that it would take 120 credits for a bachelor's degree. Lots of luck, I thought, for at the moment I could not conceive that I would stay long enough to graduate.

Then I went back to Mabie's office, but he was too busy to see me. Later he looked at my card and suggested that I take 3 hours in his beginning playwriting course, which was called "experimental theater," also 3 hours of Shakespeare under Dr. Bartholow Crawford in the English department, and to "round it off," he added with a smile, "try to get in the class called 'Economic Plants,' because you ought to have some science if you are to work for a degree." With that he again wished me luck.

I was able to get into all the classes suggested. Then it was midafternoon and I went to the office where I might apply for work. They asked me if I could type. Could I type? You bet. So they sent me over to the Children's Hospital, where I found I was to get three meals a day for three hours' work typing menus. And why not?

Next, I went to the housing office. They told me of some rooms available to students in town. I looked at the list and trudged off to the 
one that seemed cheapest. It was some distance from the school, but the lady was nice and said I could have a room for $\$ 6$ a month if I helped her get groceries on Saturdays.

Off I went to the Worthleys, who were interested in hearing an account of my adventures. They insisted on giving me supper, after which I carried my bags to my new lodging.

The very next day I started classes as well as work and meals at the hospital. I also had a call to stop at Mr. Mabie's office, where he said it occurred to him that because I was "more mature" than the usual freshman and had had so much in the way of "experience," I might be able to qualify for advanced credit in some courses. This might put me ahead toward the degree without actually having to take some of the classwork. He said to look over the courses which I thought I could qualify for without taking them, and then go to the Dean of Liberal Arts, who would know what to do. He said he would call the dean and explain.

That night I read the assignment on Shakespeare and spent some time going through the university catalog, checking off courses I thought, from the description, I might get credit for. I totaled them up and it came to almost 60 credits, or two years of work! Many were in speech and drama of course, a good number in the English department, and a few scattered elsewhere.

The next day I went to my "Economic Plants" class and learned a lot about wheat, corn, and oats. Then, after work at the hospital, I went to the dean's office. I handed the list to a young lady who said, "Oh yes, Mr. Mabie called the dean about you." She then took the list into the dean's private office. There was a pause of about five minutes, when he came to the door and motioned me inside.

"Well," he said, holding up my list, "this is quite a list you have here." I must have smiled. "However," he continued, "when Professor Mabie talked to me, I thought he meant you might qualify for a few classes in his department." I did not know how to answer that to my advantage, so I kept quiet. He stood up, looked around, sat down again in thought. Then he smiled and said, "I'll tell you want we'll do, son; we will have the English department and others give you examinations, and if they think you qualify after seeing the results, well, we may be able to give you credit." "I certainly hope so," I must have muttered nervously.

The following afternoon I had a call to see Mr. Mabie again. After the usual long wait, he motioned me to a seat. He glanced at the list of courses I had given to the dean, who must have sent him a copy. A smile flitted across his face as he looked up at me. "So you think you know all about the subjects in these courses?" he asked, waving the paper at me. "Well," I stammered, "perhaps not all but I . . . ." He raised his hand 
for me to stop, I suppose so that I would not embarrass both of us.

"Maybe you do, for all I know," he continued. "So it is now up to you to prove your knowledge and satisfy all the departments. You know that, don't you?" I nodded in the affirmative. "The idea, suggested by the dean, is that you be given what would amount to final examinations for each semester, in all the courses you have listed. They will be given in the next few days, and you are to check with the offices of various departments regarding the times and places."

"Yes, sir, thank you sir," I replied, rising from my chair. "And, of course, it applies to courses in my department," he added, staring straight at me. "You can check with my secretary tomorrow and she will put you in touch with instructors assigned to our classes who will be in charge of examinations."

I again thanked him and left, knowing from the way he had stared at me that he was not about to give further aid. I first obtained a booklist from the English department, concerned with classes I was to be tested in. The library supplied those books I was not familiar with. I was lucky that my parents had taken me to the public library every Saturday when I was a small boy, and instilled in me a habit of frequenting libraries and reading books. Many of those used in freshman and sophomore English at Iowa were familiar to me. As it was, I took a big armful of books to my room that evening. And so it went with other courses.

Two days later I took three hours in the morning and three hours in the afternoon, for two days running, covering the above courses. And so it went with all the others, until by the following Monday I had covered the list.

No need to go into more details, except to say I received grades, mostly C's and B's, but all passing, except for one course in the Department of Speech and Drama. Now, I had worked a great many hours back in Cleveland, "lighting" plays which were produced there, and I really thought I knew quite a lot from the experience. But the examination consisted of questions related to technical things, such as "the focal length of lenses," and "color values of gelatines." I failed the course in stage lighting.

In retrospect, I believe the departments and their teachers were very kind to me. For the rest, indeed it was because of all the reading I had previously done, together with experiences in many areas and an ability to write and use the language far better than most freshmen and sophomores at the college level.

My writing of plays in the Experimental Class, taught by Mr. Mabie, was not very exciting. I struggled to learn how to construct, for one thing, and it was good for me in the long run. Writing "scenes" was easy, 
building "plays" difficult.

At the end of the semester I began to run out of money and had to think of my bus fare back to Cleveland for the summer, where I expected to work. With some difficulty I managed to obtain a $\$ 50$ loan from a student fund and I returned to Cleveland. Luckily I was able to get regular work through the Teamsters' Union. Through the summer I saved all I could and ate sparingly. In addition I read a great many books about the theater and stagecraft. I decided not only to learn more about the world of drama, but also to improve my knowledge in many areas of technology. In doing so I came up with the idea that I would write a "Glossary of the Theater," which I did. Whenever reading I would make notes regarding the meaning of words or expressions indigenous, you might say, to the theater. This not only helped to reinforce my own understanding, but $I$ hoped that it might eventually be useful to others. First day back at school I saw Mr. Mabie, and he asked how many plays I had written over the summer. I explained that I had not written a single play, but learned a lot about the theater, dramatic construction, and also worked to save enough to return.

Mabie nodded, held up my glossary, and remarked that he hadn't seen one like it before. Then he said, "How would you like a job as ticket manager at the theater?"' I was stunned. When I said I would like it very much he replied, "The job pays $\$ 50$ a month.” What a relief! And I was also able to obtain a dishwashing job at the hospital for three meals a day. Then I was fortunate to find a secretary from the business office who volunteered to help me set up the ticket office, arrange the subscription system, and keep the books. I was given the combination to a massive old safe in the ticket office and felt quite important. I discovered in some records in the office that the previous year two men actually were paid to do my present job. One was called the business manager and received $\$ 60$ a month, the other assistant manager $\$ 30$ per month, so Mr. Mabie saved $\$ 360$ over the nine-month school year. This was one of the many reasons the head of the department was so successful. He was delightfully artful. For instance, I later found out that when I arrived in Iowa City for the first time he was desperately trying to find an actor to play the role of Maskelyn in a play he himself was directing as a major production, entitled Clive of India. Although it was not, perhaps, a key reason for him to help me so much at that time, it certainly helped my cause, and I was promptly cast and had the added burden of rehearsals while trying to accustom myself to the mysteries of university life! Mr. Mabie was a very resourceful and delightfully devious man.

I spent some time in the ticket office writing a full-length play, something I had not ventured to do before. My aim was to dramatize a 


\section{The Huturersity Theatre}

School of Fine Arts

University of Iowa, Iowa City

\section{The Tixperimental Uheatre Sominar}

Course (Speech 211, 212)

Department of Speech and Dramatic Art

presents

For the first time on any stage

Evenings of October 27 and 28, 1938

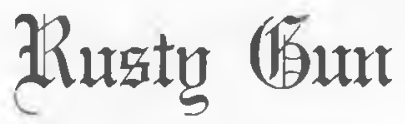

a folk-tale of the west

by

Norman Felton

“. . . western noise tools ' $n$ '

smoke wag'ns

got rusty 'round eighteen

eighty-one, an' they ain't never

got polished up bright since...."

Directed by Marian Galloway

CHARACTERS

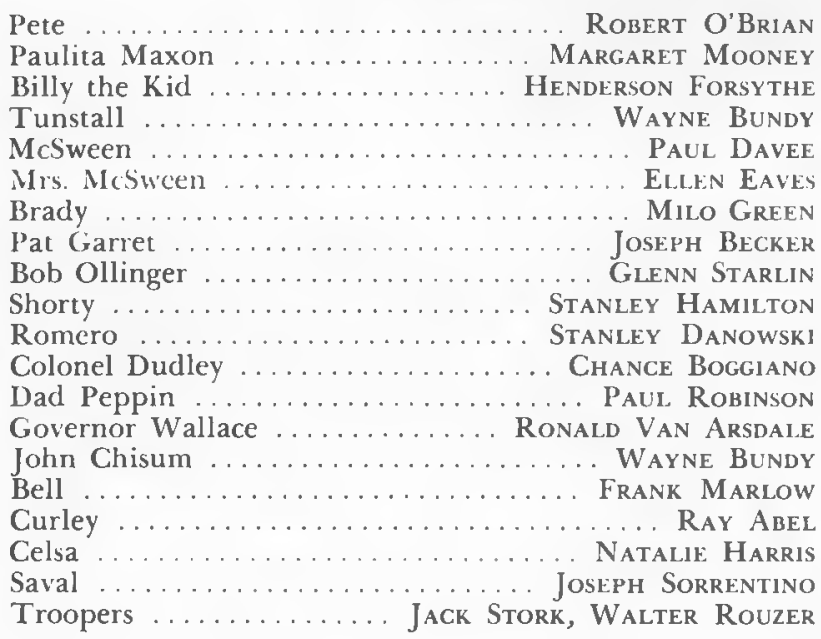

A portion of the program for the University Theatre production of Norman Felton's Rusty Gun. The role of Billy the Kid was acted by Henderson Forsythe, who has more recently appeared in the TV series "As the World Turns" and in other productions. From a copy in The University of lowa Archives. 

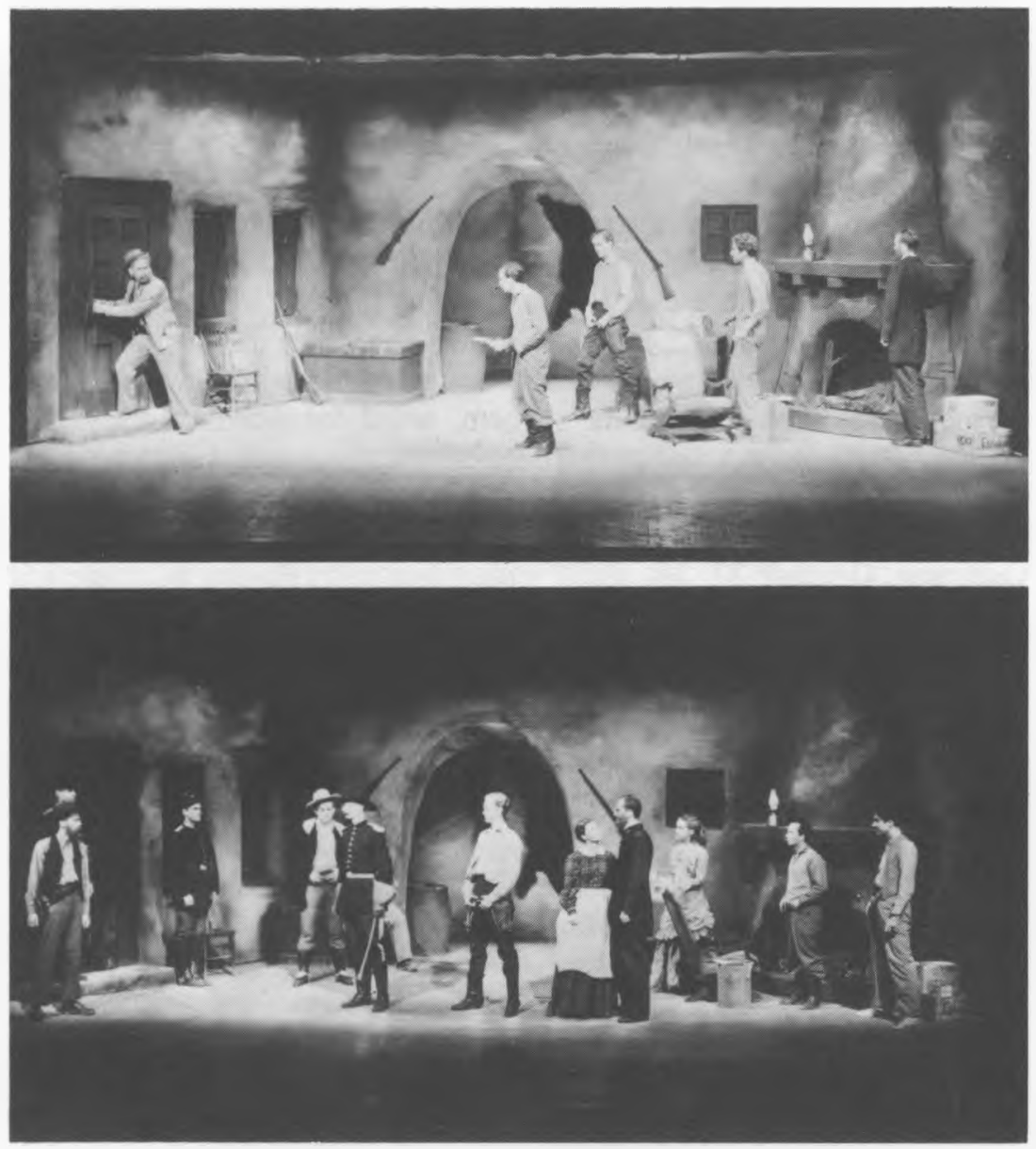

Two scenes from the premiere performance of the play Rusty Gun by Norman Felton, at The University Theatre, lowa City, October 27, 1938. From photographs in The University of Iowa Archives. 
period in the life of the young Billy the Kid, a sometime hero in the West during the nineteenth century. I had first become interested in him when I was in Seattle working on the docks for a few days with a couple of men from New Mexico. They told some wild tales of the outlaw, saying that he was born and died not far from where they had lived. I later found that they were in error on a number of points, but they had interested me enough to do some research at the library. Though it might have seemed unusual for an Englishman to write a play about a Western desperado, I read my outline at Mabie's seminar, and he approved.

It was in Mabie's seminar, consisting of five developing playwrights, that I met Tom Williams, later known as "Tennessee" Williams I believe I can safely say that none of us in the group would have bet a nickel on him becoming a successful writer. Each week we were expected to present, or read, something we had written. Tom never brought in anything until the last weeks of the seminar, and what he read was a dramatization, using Browning's poem, word for word, of "My Last Duchess." He later went on to become the foremost American playwright of the twentieth century!

My play, Rusty Gun, was produced at lowa, directed by Marian Galloway, October 27, 28, 1938, with a fine cast. Playing Billy the Kid was Henderson Forsythe, who later became a fine Broadway actor, receiving a Tony Award for a starring role in The Best Little Whorehouse in Texas.

The biggest event of my life was to come when Margaret Free, Mabie's secretary, invited me to have dinner at her apartment together with a young man, Harry Tennant. In addition, a young woman arrived, Aline Stotts, with whom she was considering sharing the apartment. I fell in love with Aline that evening. I'd met many girls before, but none so vivacious, intelligent, and exciting as she was. 